УДК 811.511.131’27

\title{
Л. Л. Карпова
}

\author{
МОРФОЛОГИЯ ЛИЧНЫХ МЕСТОИМЕНИЙ \\ В НИЖНЕЧЕПЕЦКОМ ДИАЛЕКТЕ УДМУРТСКОГО ЯЗЫКА
}

Статья посвящена описанию специфики личных местоимений нижнечепецкого диалекта, входящего в северное наречие удмуртского языка. Актуальность исследования обусловлена необходимостью комплексного изучения системы местоимений в структурно-территориальных разновидностях удмуртского диалектного языка. Нижнечепецкий диалект формировался в условиях изолированности от основного ареала распространения удмуртских диалектов, в результате чего в его языковой системе выработался ряд особенностей. Предметом рассмотрения является морфологическая структура личных местоимений. Особое внимание уделено описанию специфических черт, отличающих исследуемый диалект от других говоров северноудмуртского ареала. Констатируется, что в нижнечепецком диалекте номинативные формы личных местоимений в основном совпадают с соответствующими местоимениями других удмуртских диалектов. Подробно проанализированы характерные явления в образовании и парадигмах словоизменения рассматриваемой группы местоимений. Освещены особенности в количественном составе падежей. Проведен анализ функционирования серии вторичных пространственных падежей с показателем - $\boldsymbol{H}^{\prime}$-. Выявлены отличительные явления во внешнем оформлении отдельных падежей. В частности, различительные признаки морфонологического характера наблюдаются в оформлении аккузативных форм местоимений 1-го и 2-го лица множественного числа, в особых способах образования инструментальных форм местоимений 1-го и 2-го лица в единственном и во множественном числе. Лингвистический материал интерпретируется в контексте удмуртского языкового диалектного ландшафта. Приведенные данные показывают, что по основным особенностям словоизменения личных местоимений нижнечепецкий диалект проявляет наибольшее сходство со среднечепецкими говорами северноудмуртского наречия. Исследование основано на материалах, собранных автором в результате нескольких экспедиций в период с 2014 по 2017 гг. к нижнечепецким удмуртам.

Ключевые слова: удмуртский язык, северные диалекты, нижнечепецкий диалект, грамматическая система, диалектная морфология, личные местоимения, категория падежа, формообразование, словоизменительная парадигма, форманты, диалектное варьирование.

DOI: $10.35634 / 2224-9443-2021-15-3-402-413$

В лингвистической науке до настоящего времени дискуссионным и спорным остается вопрос о статусе местоимений как самостоятельной части речи. Занимая особое место среди других частей речи, местоимения отличаются от знаменательных частей речи морфологической и функциональной неоднородностью входящих в этот класс слов, отсутствием собственного грамматического значения, отличающего их от грамматического значения других частей речи, а также отсутствием особых, характерных только для местоимения синтаксических функций. 
Научные традиции в изучении местоимений удмуртского языка, заложенные в первых описательных грамматиках [Сочиненія 1775, 59-64; Wiedemann 1851], неразрывно связаны с исследованием данной части речи в общефинно-угорском аспекте [Balázs 1973; Майтинская 1969]. Системному описанию пермских местоимений посвящены труды Г. В. Федюневой [Федюнева 2008], Ш. Чуча [Csúcs 2005] и др. Отдельные вопросы, относящиеся к категории местоимения в удмуртском языке, нашли отражение в разделах нормативных грамматик удмуртского языка [ГСУЯ 1962, 167-187; УКК 2011, 88-107], также в работах В. К. Кельмакова [Кельмаков 1998, 134-140; 2005, 79-81], И. В. Тараканова [Тараканов 2003], С. А. Максимова [Максимов 2019, 390-402]. Несмотря на наличие серьезных разработок по удмуртским местоимениям, в научной литературе до сих пор не получило должного освещения диалектное многообразие данного лексико-грамматического класса слов в удмуртском языковом континууме. В связи с этим остается целый ряд вопросов, касающихся функционирования местоимений, а также особенностей проявления их морфологических и синтаксических свойств в частных диалектных системах удмуртского языка.

Предметом рассмотрения в данной работе является морфологическая структура личных местоимений нижнечепецкого диалекта удмуртского языка. Основная цель исследования - анализ вопросов падежного словоизменения, выявление вариативности и новообразований в парадигме склонения личных местоимений. Эмпирическую базу исследования составили языковые материалы диалектологических экспедиций автора в район проживания нижнечепецких удмуртов в период с 2014 по 2017 гг. Иллюстративный материал в работе приводится в фонематической транскрипции на кириллической основе, традиционно используемой в удмуртской диалектологии.

Нижнечепецкий диалект распространен на территории Слободского, Зуевского, Унинского, Фаленского и Богородского р-нов Кировской обл. Функционирование рассматриваемого диалекта в условиях изолированности от основного этнического массива и воздействие окружающих русских говоров сформировали ряд специфических особенностей фонетического, морфологического, лексического и синтаксического характера. Проблема возникновения и развития нижнечепецкого диалекта непосредственно связана с историей его носителей и процессом формирования этнической группы, этногенез которой, к сожалению, до сих пор мало исследован. Нижнечепецкий диалект (или нижнечепецкие говоры; далее - нч.) по наиболее характерным языковым явлениям входит в северное наречие удмуртского языка, в пределах которого, помимо нижнечепецкого, выделяется еще два диалекта: среднечепецкий и верхнечепецкий (далее - сч., вч. соответственно). С целью определения общности и специфики исследуемого диалекта в северноудмуртском языковом пространстве фактический материал интерпретируется в контексте других северных диалектов.

Состав местоимений нижнечепецкого диалекта по своим содержательным и структурным характеристикам во многом совпадает с системой местоимений общенационального удмуртского языка. Вместе с тем исследуемый диалект проявляет определенную специфику в структуре, семантике и словоизменении отдельных групп местоименных слов. Ряд нерешенных вопросов связан с разрядом личных местоимений, восходящих в удмуртском языке к очень древним периодам языковой истории и обнаруживающих в территориальных диалектах значительные дифференциальные признаки. Данная группа местоимений в нижнечепецком диалекте, как и в целом в удмуртском языке, представлена шестью местоимениями: мон 'я', тон 'ты', со 'он, она, оно', ми 'мы', ти 'вы', сойос (соос) 'они'. В номинативной форме личные местоимения исследуемого диалекта не проявляют больших отличий от соответствующих местоимений других удмуртских диалектов. Исключение составляет местоимение 3-го лица множественного числа, которое в косинском говоре выступает в формах сойос и соос, наиболее употребительным из которых является вариант сойос. Примеры: кос. сойос воз'мал'л'а'зы н'и пинал'л'омэ. Берез. 'Они водились уже с детьми моими'; кос. лачак помидорэ, то“ко тасас'ко н'и сойос вычак. Ок. 'Много у меня помидор, только портятся уже они вовсе'. В слободском 
говоре более широкое распространение имеет форма соос, а вариант сойос встречается спорадически. Примеры: сл. мон п о с к алан улыс'ко кал'. пинал'л'осы кошкэмын, но вэттыло сойос

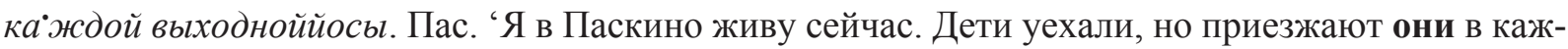
дые выходные'; сл. солэн пӧрас'эз фэрмаын ужа. кына'зы отын соос ужало. Свет. 'Его жена на ферме работает. Оба там они работают'.

Единичные случаи оформления плюральной формы 3-го лица в варианте сойос, наряду с формой соос, отмечаются в ярском, глазовском и юкаменском говорах среднечепецкого диалекта, территориально смежных с косинским говором. В других северных диалектах функционирует форма соос, которая является нормой литературного языка и наличествует в большинстве удмуртских диалектов [Карпова 2020, 241]. Отметим, что вариант сойос является архаическим: здесь сохранилась более ранняя форма суффикса множественного числа -йос, по своему происхождению восходящего к самостоятельной лексеме удм. joz коми jez 'народ, люди’ [Майтинская 1979, 83, 85-86; Rédei 1988, 351-394; Honti 1997, 82].

В удмуртских диалектах по способам образования падежных форм словоизменение личных местоимений достаточно единообразно. Расхождения возникают вследствие использования различных падежных суффиксов и суффиксальных комбинаций, некоторые различия обнаруживаются в фонемном составе морфем. Падежные парадигмы, в свою очередь, отличаются по наличию/отсутствию специфических падежей, особенностями образования отдельных форм и др. При этом следует отметить, что личные местоимения 1-го и 2-го лица склоняются иначе, чем формы 3-го лица, их словоизменение в единственном и во множественном числе также имеет свою специфику. Эти различия в определенной степени обусловлены историей происхождения и генезиса данной группы местоименных слов [Федюнева 2008, 15-73]. Общепризнанно, что личные местоимения в уральских языках восходят к разным хронологическим пластам: «...личные местоимения 1-го и 2-го лица были отделены от соответствующих указательных местоимений уже в уральском языке-основе, в то время как личные местоимения 3-го лица на базе уже сформировавшихся указательных местоимений возникли только в прафинно-угорский период» [ОФУЯ 1974, 284].

Представим парадигму словоизменения личных местоимений единственного и множественного числа в говорах нижнечепецкого диалекта.

Таблица 1

\begin{tabular}{|c|c|c|c|c|c|c|}
\hline \multicolumn{7}{|c|}{ Единственное число } \\
\hline \multirow{2}{*}{ Падеж } & \multicolumn{2}{|c|}{1 лицо } & \multicolumn{2}{|c|}{2 лицо } & \multicolumn{2}{|c|}{3 лицо } \\
\hline & сл. & кос. & сл. & кос. & сл. & кос. \\
\hline Ном. & мон & мон & тон & тон & $c o$ & $c o$ \\
\hline Акк. & монэ & монэ & тонэ & тонэ & сойэ & сойэ \\
\hline Ген. & мыннам & мыннам & тынад & тынад & солэн & солэн \\
\hline Абл. & мызнэс'mblм & мынуэс'тылм & тынээс'тылд & тынээс'тыд & солэс' & солэс' \\
\hline Дат. & Mblным & Mblнымм & mblныlд & mblныld & сольи & сольы \\
\hline Инстр. & монэнылм & монэным & тонэныд & тонэн(bld) & $\mathrm{couH}$ & соин \\
\hline Kap. & монтэк & монтэк & тонтэк & тонтэк & сотэк & сотэк \\
\hline Адв. & монйа & монйа & тонйа & тонйа & coŭa & coüa \\
\hline Аппр. & монлан' & монлан' & тонлан' & тонлан' & солан' & солан' \\
\hline Пр. ин. & мон'н'ам & мон'н'ам & $\begin{array}{c}- \\
(\text { (тон дорылн) }\end{array}$ & $\begin{array}{c}- \\
(\text { (тон дорьин) }\end{array}$ & $\mathrm{COH}^{\prime} \mathrm{blH}$ & сон'blh \\
\hline Пр. ил. & $\begin{array}{c}- \\
(\text { мон дорыl) }\end{array}$ & $\begin{array}{c}- \\
(\text { мон дорьl) }\end{array}$ & $\begin{array}{c}- \\
(\text { мон дорьl) }\end{array}$ & $\begin{array}{c}- \\
(\text { (тон дорьl) }\end{array}$ & $\mathrm{COH}^{\prime} \ni$ & $\mathrm{COH}^{\prime} \ni$ \\
\hline
\end{tabular}


Окончание таблицы 1

\begin{tabular}{|c|c|c|c|c|c|c|}
\hline Пр. эл. & $\begin{array}{c}- \\
(\text { мон дорысс })\end{array}$ & $\begin{array}{c}- \\
(\text { мон дорысс })\end{array}$ & $\begin{array}{c}- \\
(\text { мон дорысс') }\end{array}$ & $\begin{array}{c}- \\
(\text { (тон дорысc') }\end{array}$ & $с о н^{\prime} b l c^{\prime}$ & $\mathrm{coH}^{\prime} b l c^{\prime}$ \\
\hline Пр. эгр. & $\begin{array}{c}- \\
(\text { мон } \\
\text { дорьсс'эн) }\end{array}$ & $\begin{array}{c}- \\
(\text { мон } \\
\text { дорьсс'эн) }\end{array}$ & $\begin{array}{c}- \\
(\text { тон } \\
\text { дорьсс'эн) }\end{array}$ & $\begin{array}{c}- \\
(\text { мон } \\
\text { дорьсс'эн) }\end{array}$ & $\mathrm{cOH}^{\prime} \mathrm{blc}^{\prime} \ni н$ & 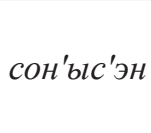 \\
\hline Пр. терм. & $\left(\begin{array}{c}- \\
(м о н \\
\text { дороз') }\end{array}\right.$ & $\begin{array}{c}- \\
(\text { мон дороз') }\end{array}$ & $($ (тон дороз') & $($ (тон дороз') & $\mathrm{COH}^{\prime}{ }^{\prime}{ }^{\prime}$ & $\mathrm{COH}^{\prime}{ }^{\prime}{ }^{\prime}$ \\
\hline
\end{tabular}

Таблица 2

\begin{tabular}{|c|c|c|c|c|c|c|}
\hline \multicolumn{7}{|c|}{ Множественное число } \\
\hline \multirow{2}{*}{ Падеж } & \multicolumn{2}{|c|}{1 лицо } & \multicolumn{2}{|c|}{2 лицо } & \multicolumn{2}{|c|}{3 лицо } \\
\hline & сл. & кос. & сл. & кос. & сл. & кос. \\
\hline Ном. & мu & мu & $m u$ & $m u$ & $\begin{array}{c}\text { cooc } \\
(\text { coŭoc })\end{array}$ & $\begin{array}{l}\text { сойос } \\
(\text { cooc })\end{array}$ \\
\hline Акк. & мил'эмэс & $\begin{array}{c}\text { мил'эмэс } \\
\text { мл эмээс }\end{array}$ & тил'эдэс & 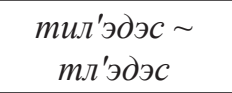 & $\begin{array}{c}\text { coocmbl } \\
(\text { coŭocmbl) }\end{array}$ & $\begin{array}{l}\text { coüocmbl } \\
\text { (coocmbl) }\end{array}$ \\
\hline Ген. & мил'ам & мил'ам & тил'ад & $\begin{array}{c}\text { тил'ад } \\
\text { тл'ад }\end{array}$ & $\begin{array}{c}\text { соослэн } \\
\text { (сойослэн) }\end{array}$ & $\begin{array}{l}\text { сойослэн } \\
\text { (соослэн) }\end{array}$ \\
\hline Абл. & мил'эс'тылм & $\begin{array}{c}\text { мил'эс'mblм } \sim \\
\text { мл ээ } c^{\prime} m b ы м\end{array}$ & тил'эс'тьлд & $\begin{array}{c}\text { тил'эс'тьлд } \sim \\
m л^{\prime} э c^{\prime} m b l \partial\end{array}$ & $\begin{array}{c}\text { соослэс' } \\
(\text { сойослэс') }\end{array}$ & $\begin{array}{l}\text { сойослэс' } \\
(\text { соослэс') }\end{array}$ \\
\hline Дат. & мил'эм & $\begin{array}{c}\text { мил'эм } ~ \\
\text { мл ээм } \\
\end{array}$ & тил'эд & $\begin{array}{c}\text { тил'эд } \\
\text { тл ээд }\end{array}$ & $\begin{array}{c}\text { соосльл } \\
\text { (сойосль) })\end{array}$ & $\begin{array}{l}\text { сойосльл } \\
\text { (соосль) }\end{array}$ \\
\hline Инстр. & мил'эмэн & $\begin{array}{c}\text { мил'эмэн } ~ \\
\text { мл'эмэн } \\
\end{array}$ & тил'эдэн & $\begin{array}{c}m и л^{\prime} э \partial э н \sim \\
m л^{\prime} \ni \partial э н\end{array}$ & $\begin{array}{c}\text { соосын } \\
\text { (сойосын) }\end{array}$ & $\begin{array}{l}\text { coüосblн } \\
\text { (coосblн) }\end{array}$ \\
\hline Kap. & митэк & митэк & титэк & питэк & $\begin{array}{c}\text { соостэк } \\
\text { (сойостэк) }\end{array}$ & $\begin{array}{l}\text { сойостэк } \\
\text { (соостэк) }\end{array}$ \\
\hline Адв. & мийа & мийа & тийа & тийа & $\begin{array}{c}\text { coocŭa } \\
\text { (coŭосйa) }\end{array}$ & $\begin{array}{l}\text { сойосйа } \\
\text { (coocйa) }\end{array}$ \\
\hline Аппр. & милан' & милан' & тилан' & тилан' & $\begin{array}{c}\text { соослан' } \\
(\text { сойослан') }\end{array}$ & $\begin{array}{l}\text { сойослан' } \\
(\text { соослан') }\end{array}$ \\
\hline Пр. ин. & мин'н'ам & мин'н'ам & тин'н'ад & тин'н'ад & $\begin{array}{c}\text { соосн'ьlн } \\
\text { (сойосн'blн) }\end{array}$ & $\begin{array}{l}\text { сойосн'blн } \\
\text { (соосн'blн) }\end{array}$ \\
\hline Пр. ил. & мин'н'ам & мин'н'ам & тин'н'ад & тин'н'ад & $\begin{array}{c}\text { соосн'э }^{\prime} \\
(\text { (сойосн'э) }\end{array}$ & $\begin{array}{l}\text { сойосн'э } \\
(\text { соосн'э })^{\prime}\end{array}$ \\
\hline Пр. эл. & мин'н'ьсс'тымм & мин'н'ысс'тылм & тин'н'ьсс'тьлд & тин'н'ьсс'тьлд & $\begin{array}{c}\text { соосн'blc' } \\
(\text { сойосн'blc') }\end{array}$ & $\begin{array}{l}\text { сойосн'blc' } \\
\left(\text { coосн'blc') }^{\prime}\right.\end{array}$ \\
\hline $\begin{array}{l}\text { Пр. } \\
\text { эгр. }\end{array}$ & мин 'н' $ы с с^{\prime} э н ы м ~$ & мин'н'ьсс'энымм & тин'н'ысс'энылд & тин'н'ысс'энылд & $\begin{array}{c}\text { соосн'blc'эн } \\
(\text { сойосн'вıс'эн) }\end{array}$ & $\begin{array}{l}\text { сойосн'blc'эн } \\
(\text { соосн'blс эн) }\end{array}$ \\
\hline $\begin{array}{c}\text { Пр. } \\
\text { терм. }\end{array}$ & мин'н'амоз' & мин'н'амоз' & тин'н'адоз' & тин'н'адоз' & $\begin{array}{c}\text { соосн'оз' } \\
(\text { сойосн'оз') }\end{array}$ & $\begin{array}{l}\text { сойосн'оз' } \\
(\text { соосн'оз') }\end{array}$ \\
\hline
\end{tabular}

1. Как видно из приведенного материала (табл. 1, 2), личные местоимения нижнечепецкого диалекта обнаруживают некоторые отличия с точки зрения количественного состава словоизменительной парадигмы.

1.1. В большинстве удмуртских диалектов система склонения рассматриваемой группы местоимений представлена 9 членами падежной парадигмы, среди которых разграничи- 
ваются 8 субъектно-объектных падежей (номинатив, аккузатив, генитив, аблатив, датив, каритив, инструменталь, адвербиаль) и 1 пространственный падеж (аппроксиматив). В отличие от этого, в отдельных северных диалектах, в частности, в нижнечепецком и среднечепецком, местоимения, подобно группе одушевленных существительных со значением человека, лица, могут принимать показатели приблизительно-местных падежей, в составе которых содержится элемент - ${ }^{\prime}$-. Этот элемент $-\mu^{\prime}-$ препозитивно присоединяется к первичным пространственным падежным формантам. Вторичные пространственные падежи в целом выражают пространственно-посессивные отношения, связанные с домом, домашним очагом, принадлежащим кому-либо [Максимов 2020, 214]. В нижнечепецком диалекте из личных местоимений формы приблизительно-местных падежей в основном принимают местоимения множественного числа (ми 'мы', ти 'вы', сойос (соос) 'они') и местоимение единственного числа со 'он, она, оно'. В рассматриваемом диалекте вышеуказанные местоимения систематически выступают в приблизительном инессиве и приблизительном иллативе, реже - в приблизительном элативе, приблизительном эгрессиве и приблизительном терминативе. Примеры: сл. ўал'л'о гла в д'и ил'л'а йка гэ н'а бордын б иг э рын улиз. картэз кулиз но, бабэныз валзэ сон'э уас'киз. Свет. 'Вначале Клавдия с Илляйка Геней в Карино жила. Муж ее умер, и вместе со свекровкой она к ней ('к ней домой’) перебралась [жить]'; кос. мон огн'ам кыли. бордаз бас'тиз пийэ, сойосн'blн кал' ульлс'ко. Мух. 'Я одна осталась. К себе забрал мой сын, у них ('уу них дома') теперь живу'; кос. мин'н'ам со вэтлиз турун ӝсут'm'аны. Ок. 'К нам ('к нам домой') он приходил сено закидывать [на сеновал]'; сл. тин'н'ад ыстоло мон ныл'л'осты кӧльныьl. Свет. 'К вам ('к вам домой') отправлю я девушек ночевать'; сл. бабушмы тодэ на уиал'л'ана кырӟанйосты, вэ'mтэ соосн'э. Свет. 'Наша бабушка знает еще старинные песни, сходите к ним ('к ним домой')'; сл. соосн'bыс'эн ти пыр'pэ в и m' а й к а доры. Пес. 'От них ('от их дома') вы зайдите к Витяйке'; сл. муми мынам с'имтэм вал. мон уас'ки сон'оз' с'ийонэн - нош отын кул'ин'чэт'т'ос вычак тийамын. Пес. 'Мама моя слепая была. Я пошла до нее ('до ее дома') с едой - а там дверные крючки полностью сломаны’. Пролативная форма указанного типа падежей в текстовых материалах нами не обнаружена.

В косинском говоре нами зафиксированы единичные примеры функционирования личного местоимения 1-го лица единственного числа мон в форме приблизительного инессива мон'н'ам. Примеры: кос. нылы биз'из вал б э р э з н' и кэ, ырӧд с'эмйайэ шэд'из. эт'и дорам. лыкти'зыл, ули'зы мынам домам, мон'н'ам. Ок. 'Дочь моя вышла замуж в Березник, в плохую семью попала. Я позвала к себе [жить]. Жили они в моем доме, у меня дома'.

С. А. Максимов, занимавшийся исследованием вторичных пространственных падежей в удмуртском языке, отмечает, что они употребляются в основном с множественным числом личных имен, а также некоторых местоимений. Причину подобного употребления описываемых падежей он объясняет тем, «что человек в своем доме (жилище) обычно проживает не один, а с членами своей семьи» [Максимов 2018, 216]. В данном вопросе мы полностью солидарны с коллегой. Материал по нижнечепецкому диалекту также подтверждает эту мысль: функционирование местоимения 1-го лица единственного числа мон в форме приблизительного инессива, не совсем свойственного местоимениям единственного числа, нами было зафиксировано в речи информанта - пожилой женщины, которая в течение длительного времени жила в своем доме одна.

Большинство исследователей происхождение вторичных пространственных падежей в удмуртском языке связывает с трансформацией серии послелогов с основой $\partial u н^{\prime}-$ 'у, около, при, возле', которая, в свою очередь, возникла от имени существительного дин' 'основание, комель; близость, околица' [Wichmann 1954, 50, 135-136; Вахрушев 1959, 236; Тепляшина 1981, 287; Кельмаков 1998, 118; Кондратьева 2011, 123; Максимов 2018, 220-225].

В верхнечепецких говорах, как и в большинстве удмуртских диалектов, аналогичные падежные формы отсутствуют: им соответствуют послеложные конструкции с послелогами с основой дин'- ‘у, около, возле, при' (верхнечепецкие говоры) [Алашеева 1999, 64] и дор- 'у, 
около, возле, при' (срединные говоры и южноудмуртские диалекты): вч. ти дин'э, сред., юж. ти доры 'к вам'; вч. со дин'ысс'эн, сред., юж. со дорыс'эн 'от него'.

1.2. Аппроксиматив личных местоимений в нижнечепецком диалекте, как и в северноудмуртском диалектном пространстве в целом, имеет тенденцию к исчезновению: формы типа монлан' 'по направлению ко мне, в сторону меня', тонлан' 'по направлению к тебе, в сторону тебя' употребляются исключительно редко и встречаются в основном в речи пожилого населения. Низкая дистрибутивная нагрузка данного падежа в северноудмуртских диалектах объясняется интралингвистическими факторами: широким употреблением послеложных конструкций (местоимение в номинативе плюс послелог пала 'по направлению к, в сторону') в указанном значении: нч. ку лыкто॰dbl н'и табрэ ми пала? Пес. 'Когда же приедете теперь в нашу сторону?'. В северноудмуртских диалектах процесс ослабления морфологического оформления аппроксиматива не только в системе местоимений, но и существительных, имеет тенденцию к дальнейшему развитию (см. об этом подробнее: [Кельмаков 1998, 117; Кондратьева 2011, 204-205]).

2. Помимо количественной разницы в системе пространственных падежей, определенные отличия рассматриваемая группа местоимений нижнечепецкого диалекта обнаруживает на уровне фонетического оформления падежных маркеров, а также способов их образования.

2.1. Аккузатив личных местоимений 1-го и 2-го лица множественного числа в удмуртских диалектах представлен несколькими вариантами суффиксов. В южноудмуртских и части срединных говоров он имеет стандартный суффикс -ыз. В отличие от этого, в северной диалектной зоне оформление аккузатива этих форм местоимений не представляет единства.

В нижнечепецких говорах в данном случае, как правило, выступает суффикс -эс: сл. кос. мил'эмэс, кос. (Сиб.) мл'эмэс 'нас', сл. кос. тил'эдэс, кос. (Сиб.) тл'эдэс 'вас'. Примеры: сл. мил'эмэс газ'эт лыд'д'аны косо. Ом. 'Нас газету заставляют читать'; сл. бэрог дурыс'эн мил'эмэс адзиз пэпэс'мыл. Свет. 'У берега нас увидела наша бабушка'; кос. слалтыныь кон'ыгубийэз мил'эмэс мумылы дышэтиз. Берез. 'Солить рыжики нас мама наша научила'; кос. вычак со вэра тл'эдэс. Сиб. 'Постоянно он вспоминает ('говорит') вас'. В говоре д. Березник (косинский говор), наряду с суффиксом -эс, спорадически встречается также аккузативный показатель -эсты: кос. мил'эмэсты мальс сн'имат' ӧт кар? Ок. 'Нас почему фотографировать не стал ты?’; кос. мил'эмэсты, ныл'л'осты, кэл'а'зы након'э’и-то куиин' нуналльь кан'и'кулэ. Берез. 'Нас, девушек, отпустили наконец-то на три дня на каникулы'.

Помимо этого, в говоре дд. Березник, Поля, Городище Зуевского р-на (входит в косинскую группу нижнечепецкого диалекта) нами зарегистрирован необычный вариант аккузатива в форме мил'эмйосты, где стандартный северноудмуртский суффикс -ты осложнен суффиксом мно-

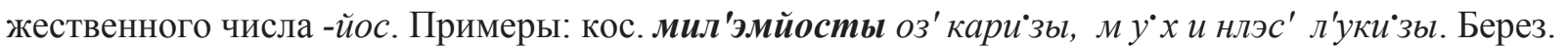
'С нами ('нас') так сделали, от [совхоза] Мухино отделили'; кос. бордаз бас'тиз мил'эмйость $\kappa u^{\prime}$ р о ф с к о й молококомбинат. Поля 'К себе присоединил нас Кировский молококомбинат'; кос. война выльлн с'о мил'эмйосты ӥайӥээ ыссйал'л'ал'л'аззъ. Гор. 'Во время войны всё нас в лес отправляли [на лесозаготовку]'. Подобный способ образования показателя аккузатива, осложненного суффиксом множественного числа, встречается и в коми-зырянских диалектах [Федюнева 2008, 63].

В отличие от нижнечепецких говоров, в ареале распространения среднечепецкого диалекта отмечается употребление аккузативных форм с аффиксами -эcmbl, -эc, -дbl, -дblc, функционирование которых не представляет единства по диалектным микросистемам. В ярском и юкаменском говорах наблюдается в основном функционирование показателей -эcmbl -эc: мил'эмэсты $\sim$ мил'эмэс 'нас', тил'эдэсты $\sim$ тил'эдэс 'вас'. В глазовском говоре прослеживается употребление личных местоимений 1-го и 2-го лица множественного числа с формантами -эсты $\sim-э c \sim-д b l$, реже - -дыс: мил'эмэсты $\sim$ мил'эмэс мил'эмды $\sim$ мил'эмдыс 'нас', тил'эдэсты $\sim$ тил'эдэс $\sim$ тил'эдды $\sim$ тил'эддыс 'вас'. В балезинском говоре среднечепецкого диалекта наиболее интенсивным употреблением отличается формант -ды. Лишь в отдельных 
говорах юго-западной части Балезинского р-на (дд. Исаково, Ушур, Кер-Нюра), территориально смежных с глазовским говором, наряду с показателем -дbl, нередко встречается также суффикс -эсты. В говорах юго-восточной части Балезинского р-на (андрейшурский куст), наряду c - $\partial b$, функционирует показатель -дыс, характерный для пограничных дебёсского и зуринского говоров верхнечепецкого диалекта.

Для кезского и северной части дебёсского говоров верхнечепецкого диалекта характерна тенденция к употреблению аккузативного показателя -ды (мил'эмды 'нас', тил'эдды 'вас'). В зуринском говоре, также в центральном и южном ареале дебёсского говора наблюдается параллельное функционирование суффиксов -ды и -дыс (мил'эмды мил'эмдыс 'нас', тил'эдды тил'эддысс 'вас').

Диахронически аккузативные суффиксы с опорным согласным -m (-d) и -c (-3), как отмечает Г. В. Федюнева, восходят к прапермскому периоду, так как имеют широкое распространение во всех пермских языках и диалектах [Федюнева 2008, 64]. Развитие показателя -эс в северноудмуртских диалектах можно представить следующим образом: в силу ассимилятивных процессов гласный $b l$ показателя аккузатива -ыз уподобляется предшествующему гласному э, в результате чего имеем -эс: мил'эмэс < мил'эмыз 'нас', тил'эдэс < тил'эдыз 'вас'. Показатель -эсты, наличествующий в среднечепецком диалекте и в косинском говоре нижнечепецкого диалекта, представляет собой контаминацию формантов аккузатива южных говоров -ыз (в описываемом диа-

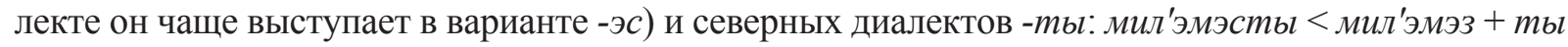
'нас'; тил'эдыстыь < тил'эдыз + mыl, тил'эдэсть < тил'эдэз + mы 'вас'. Что касается суффикса -дblc, то он также образован плеонастическим сочетанием двух вышеуказанных суффиксов, но в ином расположении: -дыс $(<-\partial b l+-b l 3)$. Аналогичный суффикс отмечается в срединных говоpax, к примеру, в прикильмезских [Загуляева 1980, 107] и средневосточных [Бушмакин 1971, 22].

2.2. Аккузатив личного местоимения 3-го лица множественного числа в нижнечепецком диалекте, подобно другим северноудмуртским диалектам, имеет стандартный показатель -mbl, участвующий, как было отмечено выше, также в образовании аккузативных форм личных местоимений 1-го и 2-го лица множественного числа. Примеры: сл. сокы ӧс ты 'шкас'кэ соосты айbl-мумы, жал' $а$ 'зы, кэрэк. Крас. 'Тогда не стали ругать их родители, пожалели, видимо'; кос. папайос кукчало клубн'икээз, мыным сойосты с'эткайэн пришлос' пытсаны. Берез. 'Птицы клюют клубнику, мне пришлось их сеткой прикрыть'. В говорах южной диалектной зоны в данной функции последовательно выступает формант -blз: сев. coocmbl, юж. coocbls 'их'.

Северноудмуртский вариант оформления аккузатива множественного числа имеет место также в части срединных говоров [Бушмакин 1971a, 269] и в бесермянском наречии (наряду с формантом -ъ3) [Тепляшина 1970a, 184; Люкина 2016, 92]. В языке бесермян подобная маркировка выработалась, по-видимому, под влиянием соседних северных говоров.

2.3. Датив личных местоимений 1-го и 2-го лица множественного числа в нижнечепецком диалекте, как и в других северных диалектах, выражается без падежного форманта, т.е. датив имеет усеченную форму: мил'эм 'нам', тил'эд 'вам'. Примеры: сл. бубойка дэрэм мил'эм вуриз

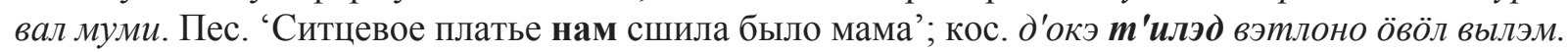
тан' бордамы нэ улэ кышно мурт, соин вэрас'коно вылэм тил'эд. Сиб. 'Далеко не нужно было вам ходить. Вот рядом с нами живет женщина, с ней нужно было побеседовать вам’

В большинстве удмуртских диалектов, в частности, в говорах южного диалектного ареала и центральных говорах, датив личных местоимений 1-го и 2-го лица множественного числа образуется с помощью суффикса -ль: юж. сред. мил'эмльь 'нам', тил'эдльь 'вам'.

Употребление краткой формы датива находит параллели и в северо-западных комизырянских диалектах [Федюнева 2008, 62; Попова, Сажина 2014, 161]. Известный финноугровед Д. В. Бубрих объяснял данный факт влиянием датива 1-го и 2-го лица единственного числа, которые образованы без суффикса -льь [Бубрих 1949, 104].

2.4. В нижнечепецком диалекте, как и в других северных диалектах, формы инструменталя от личных местоимений 1-го и 2-го лица единственного числа имеют расширенный с помо- 
щью притяжательного суффикса вариант: монэным '(со) мной', тонэныд '(с) тобой'. Примеры: кос. биз'из со мынылм, оз' ик монэнымм лыктиз улыны б э $р$ э з н' и кэ. Берез. 'Вышла замуж она за меня, так и со мной приехала жить в Березник’; сл. уармумыдэ, ныльl, э’н аналты, тонэныд валзэ н'и соль улоно. ойигн'аз сольл с'экыт н'и улыны. Ом. 'Свекровку свою, доченька, не оставляй, вместе с тобой уже ей нужно жить. Одной ей тяжело уже жить'.

В отдельных населенных пунктах (дд. Сибирь, Астрахань Унинского р-на Кировской области) бытования косинского говора нижнечепецкого диалекта наряду с расширенным вариантом параллельно отмечается и неосложненная форма инструменталя - монэн, тонэн. Примеры: кос. зӧкэз нblлыз, инвал'и'тка со, монэн улэ. Сиб. 'Старшая её дочь, инвалид она, со мной живет'; кос. мынылм картыли ӝсутоно, тонэн вэрас'кыны врэмайэ ӧвӧл. Сиб. 'Мне нужно картошку окучивать, с тобой общаться времени нет'. Функционирование вариантов монэн, тонэн в данных говорах, по нашему мнению, объясняется влиянием соседнего сурвайско-поломского говора, для которого характерны подобные формы. Носителями сурвайско-поломского говора являются удмурты-калмезы, язык которых относится к среднезападным говорам. Отметим, что удмурты-ватка и удмурты-калмезы Унинского р-на, проживающие в пределах одной территории, находятся в тесных социальнокультурных контактах, что способствует определенному взаимовлиянию их говоров.

Соответствующие расширенные формы местоимений мон 'я', тон 'ты' в инструментале функционируют в бесермянском наречии [Тепляшина 1970а, 183; Люкина 2016, 91-92], в отдельных средневосточных говорах [Бушмакин 1971a, 269]. Параллельное функционирование форм монэн $\sim$ монэным, тонэн $\sim$ тонэныд зафиксировано в говоре д. Старая Игра Граховского р-на [Атаманов 2005, 180]. Наличие в данном говоре расширенного варианта указанных местоимений, не характерного для южноудмуртских говоров, вполне объяснимо: в заселении данной местности, как отмечает М. Г. Атаманов [2005, 24], принимало участие поломское население, местом формирования которого была верхняя Чепца (территория современного Кезского, Дебёсского и Балезинского р-нов).

Следует отметить, что в говорах южной диалектной зоны, а также в отдельных срединных говорах инструментальные формы от местоимений 1-го и 2-го лица единственного числа выступают достаточно однородно и образуются присоединением к основе номинатива стандартного суффикса -эн: монэн 'со мной', тонэн 'с тобой'.

2.5. В нижнечепецком диалекте инструменталь личных местоимений 1-го и 2-го лица множественного числа представлен формами мил'эмэн, мл 'эмэн 'с нами', тил'эдэн, тл'эдэн 'с вами', которые характерны в целом также для среднечепецкого диалекта. Примеры: сл. а кал' чик уг

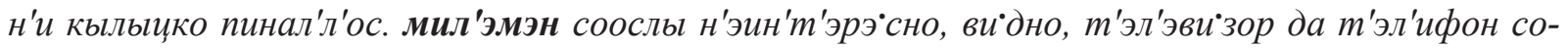
ослэн мэд луоз. НМоч. 'А сейчас совсем не слушаются дети. С нами им неинтересно, видно, чтоб телевизор да телефон у них был'; сл. пэпэс'мы корка пуктиз казарма кад'. кал' мил'эмэн со улэ. Свет. 'Наш дедушка дом построил [большой], как казарма. Сейчас с нами он живет'. Отметим, что в материалах Т. И. Тепляшиной, исследовавшей нижнечепецкие говоры в 1960-е гг., представлена также форма миленым [мил'эным ] [Тепляшина 1970, 175]. Примеров употребления указанной формы в речи современных нижнечепецких удмуртов нами не зафиксировано.

Для верхнечепецкого диалекта характерными являются формы мил'эным $\sim$ мил'энылмbl, тил'эныд тил'энылды. В большинстве удмуртских диалектов инструментальные формы множественного числа от местоимений 1-го и 2-го лица выступают в виде мил'эмын 'с нами', тил'эдын 'с вами', совпадающие с формами литературного языка.

Нижнечепецкий и среднечепецкий показатель -эн инструменталя в формах мил'эмэн, тил'эдэн, мл'эмэн, тл'эдэн возник в результате ассимилятивного явления, когда гласный ы показателя инструменталя -ын уподобляется предшествующему гласному э: мил'эмэн < мил'эмын, тил'эдэн < тил'эдын.

Верхнечепецкие формы мил'эным, мил'энымы 'с нами', тил'эныд, тил'эныды 'с вами' отличаются от соответствующих форм преобладающего большинства удмуртских диалектов иным расположением компонентов показателя инструменталя: если в последних он представ- 
лен комбинацией лично-притяжательного суффикса множественного числа и падежного показателя, то в верхнечепецких говорах эти составляющие выступают в иной последовательности - падежный показатель -эн плюс лично-притяжательный суффикс единственного или множественного числа $-м(-M b l),-\partial(-\partial b l)$. Подобные соответствия образования инструментальных форм с помощью лично-притяжательных суффиксов имеют место в бесермянском наречии [Тепляшина 1970a, 185; Люкина 2016, 92, 93], также в пограничных с верхнечепецким диалектом средневосточных говорах [Бушмакин 1971a, 270]. Аналогичное образование указанных форм наблюдается также в удорском и ижемском коми-зырянских диалектах [Федюнева 2008, 65].

Таким образом, приведенный языковой материал дает основание утверждать, что в нижнечепецком диалекте северноудмуртского наречия обнаруживаются определенные отличительные явления в морфологической структуре личных местоимений. На междиалектном уровне различия проявляются в количественном составе словоизменительной парадигмы, в неодинаковой дистрибуции падежных форм и внешнем оформлении падежных маркеров. В частности, особенности морфонологического характера прослеживаются в оформлении аккузативных форм местоимений 1-го и 2-го лица множественного числа, в особых способах образования инструментальных форм местоимений 1-го и 2-го лица в единственном и во множественном числе. Вариативность в формообразовании личных местоимений в удмуртском диалектном языке свидетельствует об инновационных процессах в их становлении и генезисе.

\section{УСЛОВНЫЕ СОКРАЩЕНИЯ}

а) языки и диалекты: вч. - верхнечепецкий диалект северного наречия удмуртского языка; кос. - косинский говор нижнечепецкого диалекта; нч. - нижнечепецкий диалект северного наречия удмуртского языка; сев. - северное наречие удмуртского языка; сл. - слободской говор нижнечепецкого диалекта; сред. - срединные говоры удмуртского языка; сч. - среднечепецкий диалект северного наречия удмуртского языка; удм. - удмуртский язык; юж. - южное наречие удмуртского языка;

б) населенные пункты по говорам нижнечепецкого диалекта:

слободской говор: Крас. - д. Красногорье, Слободской р-н; НМоч. - д. Нижнее Мочагино, Слободской р-н; Ом. - д. Омсино, Слободской р-н; Пас. - д. Паскино, Слободской р-н; Пес. - д. Пески, Слободской р-н; Свет. - д. Светозарево, Слободской р-н;

косинский говор: Берез. - д. Березник, Зуевский р-н; Гор. - д. Городище, Зуевский р-н; Мух. с. Мухино, Зуевский р-н; Ок. - п. Октябрьский, Зуевский р-н; Поля - д. Поля, Зуевский р-н; Сиб. - д. Сибирь, Унинский р-н.

\section{ЛИТЕРАТУРА}

Атаманов М. Г. Песни и сказы ушедших эпох. Ижевск: Удмуртия, 2005. 248 с.

Бубрих Д. В. Грамматика литературного коми языка. Л.: Изд-во Ленингр. ун-та, 1949. 201 с.

Бушмакин С. К. Фонетические и морфологические особенности средневосточных говоров удмуртского языка: автореф. дис. ... канд. филол. наук. Тарту, 1971. 28 с.

Бушмакин С. К. Фонетические и морфологические особенности средневосточных говоров удмуртского языка: дис. ... канд. филол. наук. Ижевск; М., 1971а. 397+350 с.

Вахрушев В. М. Об особенностях говоров северного диалекта удмуртского языка // Записки УдНИИ. 1959. Вып. 19. С. 228-241.

ГСУЯ 1962 - Грамматика современного удмуртского языка. Фонетика и морфология. Ижевск, $1962.372 \mathrm{c}$.

Загуляева Б. ШІ. Морфологические особенности прикильмезских говоров удмуртского языка // Fenno-Ugristica 6. Тарту, 1980. С. 103-110.

Карпова Л. Л. Диалекты северного наречия удмуртского языка: формирование и современное состояние. Ижевск: МарШак, 2020. 563 с.

Кельмаков В. К. Краткий курс удмуртской диалектологии: Введение. Фонетика. Морфология. Диалектные тексты. Библиография. Ижевск: Изд-во Удм. ун-та, 1998. 386 с.

Кельмаков В. К. К проблеме морфемного членения удмуртских личных местоимений // Congressus Decimus Internationalis Fenno-Ugristarum, Joshkar-Ola, 15.08-21.08.2005. Joshkar-Ola, 2005. Pars II. Linguistica: Summaria acroasium in sectionibus. C. 79-81. 
Кондратьева Н. В. Формирование падежной системы в удмуртском языке. Ижевск: Удм. ун-т, 2011. $154 \mathrm{c}$.

Люкина Н. М. Фонетико-морфологические особенности языка лекминских и юндинских бесермян. Ижевск: Институт компьютерных исследований, 2016. 200 с.

Майтинская К. Е. Местоимения в языках разных систем. М.: Наука, 1969. 308 с.

Майтинская K. Е. Историко-сопоставительная морфология финно-угорских языков. М.: Наука, 1979. $263 \mathrm{c}$.

Максимов С. А. Северноудмуртско-коми ареальные языковые параллели: лексика, фонетика, морфология. Ижевск, 2018. 336 с.

Максимов С. А. К проблеме категории инклюзивности у местоимений в удмуртском языке // Ежегодник финно-угорских исследований. 2019. Т. 13. Вып. 3. С. 390-402.

ОФУЯ 1974 - Основы финно-угорского языкознания. Вопросы происхождения и развития финноугорских языков. М.: Изд-во «Наука», 1974. 484 с.

Попова Р. П., Сажина С. А. Фонетические и морфологические особенности коми диалектов (сравнительный аспект исследования). Сыктывкар: Изд-во СыктГУ, 2014. 272 с.

Сочиненія 1775 - Сочиненія принадлежащія къ грамматикъ вотскаго языка. Въ Санктпетербургъ при Императорской Академїи наукъ 1775 года. 113 с. [В кн.: Первая научная грамматика удмуртского языка. Ижевск, 1975. 16 с. +113 с. +17 с.].

Тараканов И. В. Туала удмурт кыл: Нимвоштос. Ижкар, 2003. 32 б.

Тепляшина Т. И. Нижнечепецкие говоры северноудмуртского наречия // Записки УдНИИ. 1970. Вып. 21. Филология. С. 156-196.

Тепляшина Т. И. Язык бесермян. М.: Наука, 1970а. 288 с.

Тепляшина Т. И. О новых удмуртских падежах // Congressus Quintus Internationalis Fenno-Ugristarum, Turku 20.-27.08.1980. Turku, 1981. Pars VI. Dissertationes sectionum: phonologica et morphologica, syntactica et semantica. C. 285-292.

УКК 2011 - Удмурт кыллэн кылкабтодосэз (морфология) (Морфология удмуртского языка). Ижевск: Изд-во «Удм. ун-т», 2011. 408 с.

Федюнева Г. В. Первичные местоимения в пермских языках. Екатеринбург: УрО РАН, 2008. 427 с.

Balázs J. Funktionswerte der Pronominalität. Budapest, 1973. $240 \mathrm{~s}$.

Csúcs $S$. Die Rekonstruktion der permischen Grundsprache. Budapest: Akadémiai Kiadó, 2005. $410 \mathrm{~s}$.

Honti L. Numerusprobleme (Ein Erkundungszug durch den Dschungel der uralischen Numeri) // FinnischUgrische Forschungen. 1997. Bd. 54. H. 1-2. S. 1-126.

Rédei K. Geschichte der permischen Sprachen // The Uralic Languages. Description, history and foreign influences / Denis Sinor (ed.). Leiden - New York - København - Köln, 1988. S. 351-394.

Wichmann Y. Wotjakische Chrestomathie mit Glossar. Anhang: Grammatikalischer abriss von D. R. Fuchs. Helsinki, 1954. V + $134 \mathrm{~s}$.

Wiedemann F. J. Grammatik der wotjakischen Sprache nebst einem kleinen wotjakisch-deutschen und deutsch-wotjakischen Wörterbuche. Reval, 1851.390 s.

Поступила в редакцию 23.04.2021

Карпова Людмила Леонидовна, доктор филологических наук, ведущий научный сотрудник ФГБУН «Удмуртский федеральный исследовательский центр УрО РАН» 426067, Россия, г. Ижевск, ул. Барамзиной, 34 e-mail: karpovalud@rambler.ru

\section{L. Karpova \\ MORPHOLOGY OF PERSONAL PRONOUNS IN THE LOWER CHEPTSA DIALECT OF THE UDMURT LANGUAGE}

DOI: $10.35634 / 2224-9443-2021-15-3-402-413$

The article is devoted to the description of the peculiarities of the pronominal deixis in the Lower Cheptsa dialect which is a part of the Northern Udmurt dialect. The relevance of the study is due to the need for a comprehensive 
research of system of pronouns in the context of territorial varieties of Udmurt language. The Lower Cheptsa dialect developed isolatedly from the basic area of distribution of the Udmurt dialects, as a result of which a number of features were formed in its language system. The paper considers the morphological structure and usage of personal pronouns. The author focuses on specific characteristics distinguishing the studied dialect from other Northern Udmurt subdialects. The study demonstrates that in the Lower Cheptsa dialect the nominative forms of personal pronouns largely coincide with the corresponding such pronouns of other Udmurt dialects. The researcher also highlights characteristic phenomena in the inflectional system of personal pronouns, reveals some features in the number of cases, analyzes the functioning of a series of secondary spatial cases with marker $-n^{\prime}-$, and focuses on specific phenomena in the form of some cases. In particular, distinctive features of a morphonological nature are observed in the design of accusative forms of the $1^{\text {st }}$ and $2^{\text {nd }}$ person plural pronouns, in special ways of forming instrumental forms of the $1^{\text {st }}$ and $2^{\text {nd }}$ person pronouns in the singular and plural. Linguistic data are analyzed and interpreted in the context of the Udmurt language dialectic landscape. The data presented show that according to the main features of inflection of personal pronouns the Lower Cheptsa dialect bears closest similarities to the Middle Cheptsa subdialects of the Northern Udmurt dialect. The research is based on the materials collected by the author during several expeditions to the Lower Cheptsa Udmurts from 2014 to 2017.

Keywords: Udmurt language, Northern dialects, Lower Cheptsa dialect, grammar system, dialectal morphology, personal pronouns, category of Case, formation, inflectional paradigm, formants, dialectal variation.

Citation: Yearbook of Finno-Ugric Studies, 2021, vol. 15, issue 3, pp. 402-413. In Russian.

\section{REFERENCES}

Atamanov M. G. Pesni i skazy ushedshikh epokh [Songs and tales of past ages]. Izhevsk: Udmurtiya Publ., 2005. 248 p. In Russian.

Bubrikh D. V. Grammatika literaturnogo komi yazyka [The literary Komi Grammar]. Leningrad: Leningr. Univ. Publ., 1949. 201 p. In Russian.

Bushmakin S. K. Foneticheskie i morfologicheskie osobennosti srednevostochnykh govorov udmurtskogo yazyka: Aftoref. dis. kand. filol. nauk [Phonetic and morphological features of the Middle-Eastern subdialects of the Udmurt language. Extended abstract of Cand. philol. sci. diss.]. Tartu, 1971. 397+350 p. In Russian.

Bushmakin S. K. Foneticheskie i morfologicheskie osobennosti srednevostochnykh govorov udmurtskogo yazyka: Dis. kand. filol. nauk [Phonetic and morphological features of the Middle-Eastern subdialects of the Udmurt language. Cand. philol. sci. diss.]. Izhevsk; Moscow, 1971a. 397+350 p. In Russian.

Vakhrushev V. M. Ob osobennostyakh govorov severnogo dialekta udmurtskogo yazyka [On the peculiarities of the subdialects of the Northern dialect of the Udmurt language] // Zapiski [Proceedings]. Izhevsk, 1959. Issue 19. Pp. 156-196. In Russian.

GSUYa - Grammatika sovremennogo udmurtskogo yazyka: fonetika i morfologiya [Grammar of the modern Udmurt language: phonetics and morphology]. Izhevsk, 1962. 376 p. In Russian.

Zagulyaeva B. Sh. Morfologicheskie osobennosti prikil'mezskikh govorov [Morphological features of the Kilmez subdialects // Fenno-Ugristica 6. Tartu, 1980. Pp. 103-110. In Russian.

Karpova L. L. Dialekty severnogo narechiya udmurtskogo yazyka: Formirovanie i sovremennoe sostoyanie [The dialects of the Northern dialect of the Udmurt language: Formation and current state]. Izhevsk: MarShak Publ., 2020. 563 p. In Russian.

Kel'makov V. K. Kratkiy kurs udmurtskoy dialektologii: Vvedenie. Fonetika. Morfologiya. Dialektnye teksty. Bibliografiya [A short course on Udmurt dialectology: Introduction. Phonetics. Morphology. Dialectal texts. References]. Izhevsk: Udm. Univ. Publ., 1998. 386 p. In Russian.

Kel'makov V. K. K probleme morfemnogo chleneniya udmurtskikh lichnykh mestoimenii [To the problem of morphemic articulation of Udmurt personal pronouns] // Congressus Decimus Internationalis FennoUgristarum. 15.08-21.08.2005. Joshkar-Ola, 2005. Pars II. Linguistica: Summaria acroasium in sectionibus. Pp. 79-81. In Russian.

Kondrat'eva N. V. Formirovanie padezhnoi sistemy v udmurtskom yazyke [Formation of the case system in the Udmurt language]. Izhevsk: Udm. Univ. Publ., 2011. 154 p. In Russian.

Lyukina N. M. Fonetiko-morfologicheskie osobennosti yazyka lekminskikh i yundinskikh besermyan [Phonetic and morphological features in the language of the Lekma and Yunda Besermians]. Izhevsk: Institute for Computer Research Publ., 2016. 200 p. In Russian. 
Maitinskaya K. E. Mestoimeniya v yazykakh raznykh system [Pronouns in languages of different systems]. Moscow: Nauka Publ., 1970. 308 p. In Russian.

Maitinskaya K. E. Istoriko-sopostavitel'naya morfologiya finno-ugorskikh yazykov [Historical and Comparative Morphology of the Finno-Ugric Languages]. Moscow: Nauka Publ., 1979. 263 p. In Russian.

Maksimov S. A. Severnoudmurtsko-komi areal'nye yazykovye paralleli: leksika, fonetika, morfologiya [North Udmurt-Komi areal linguistic parallels: vocabulary, phonetics, morphology]. Izhevsk, 2018. 336 p. In Russian.

Maksimov S. A. K probleme kategorii inklyuzivnosti u mestoimenii v udmurtskom yazyke [On the problem of the category of Clusivity in the Udmurt language] // Ezhegodnik finno-ugorskikh issledovanii [Yearbook of Finno-Ugric Studies]. 2019. Vol. 13. Issue 3. Pp. 390-402. In Russian.

OFUYA 1974 - Osnovy finno-ugorskogo yazykoznaniya. Voprosy proiskhozhdeniya i razvitiya finnougorskikh yazykov [Basics of Finno-Ugric Linguistics. Questions of the origin and development of the FinnoUgric languages]. Moscow: Nauka Publ., 1974. 484 p. In Russian.

Popova R. P., Sazhina S. A. Foneticheskie i morfologicheskie osobennosti komi dialektov (sravnitel'nyy aspekt issledovaniya) [Phonetic and morphological features of Komi dialects (comparative aspect of the research)]. Syktyvkar: Syktyvkar state university Publ., 2014. 272 p. In Russian.

Sochineniya 1775 - Sochineniya prinadlezhashchiya k grammatikm votskago yazyka [Writings belonging to the grammar of the Votyak language]. V Sanktpeterburgiii pri Imperatorskoj Akademiii nauk 1775 goda [In St. Petersburg at the Imperial Academy of Sciences in 1775]. 113 p. [V kn. Pervaya nauchnaya grammatika udmurtskogo yazyka. Izhevsk, 1975. Pp. 16+113+17]. In Russian.

Tarakanov I. V. Tuala udmurt kyl: Nimvoshtos [The modern Udmurt language: Pronoun]. Izhevsk, 2003. 32 p. In Udmurt.

Teplyashina T. I. Nizhnechepetskie govory severnoudmurtskogo narechiya [The Lower Cheptsa subdialects of the Northern Udmurt dialect] // Zapiski [Proceedings]. Izhevsk, 1970. Issue 21. Philology. Pp. 156-196. In Russian.

Teplyashina T. I. Yazyk besermyan [Language of the Besermyan]. Moscow: Nauka Publ., 1970a. 288 p. In Russian.

Teplyashina T. I. O novykh udmurtskikh padezhakh [On new cases in the Udmurt language] // Congressus Quintus Internationalis Fenno-Ugristarum, Turku 20.-27.08.1980. Turku, 1981. Pars VI. Dissertationes sectionum: phonologica et morphologica, syntactica et semantica. Pp. 285-292. In Russian.

UKK 2011 - Udmurt kyllehn kylkabtodosehz (morfologiya) (Morfologiya udmurtskogo yazyka) [Morphology of the Udmurt language]. Izhevsk: Udm. Univ. Publ., 2011. 408 p. In Udmurt.

Fedyuneva G. V. Pervichnye mestoimeniya v permskih yazykah [Primary pronouns in Permian languages]. Ekaterinburg: UrO RAN Publ., 2008. 427 p. In Russian.

Balázs J. Funktionswerte der Pronominalität. Budapest, 1973. 240 s. In German.

Csúcs S. Die Rekonstruktion der permischen Grundsprache. Budapest: Akadémiai Kiadó, 2005. 410 s. In German.

Honti L. Numerusprobleme (Ein Erkundungszug durch den Dschungel der uralischen Numeri) // FUF. Helsinki, 1997. Bd. 54. H. 1-2. S. 1-126. In German.

Rédei K. Geschichte der permischen Sprachen // The Uralic Languages. Description, history and foreign influences / Denis Sinor (ed.). Leiden - New York - København - Köln, 1988. S. 351-394. In German.

Wichmann Y. Wotjakische Chrestomathie mit Glossar. Anhang: Grammatikalischer Abriss von D. R. Fuchs. Helsinki, 1954. V + 134 s. In German.

Wiedemann F. J. Grammatik der wotjakischen Sprache nebst einem kleinen wotjakisch-deutschen und deutsch-wotjakischen Wörterbuche. Reval, 1851. 390 S. In German.

Received 23.04.2021

Karpova Ludmila Leonidovna,

Doctor of Sciences (Philology), Leading Research Associate Udmurt Federal Research Center of the Ural Branch of the Russian Academy of Sciences 34, T. Baramzinoy st., Izhevsk, 426067, Russian Federation, e-mail: karpovalud@rambler.ru 